\title{
Relative Biochemical Basis of Susceptibility in Commercial Wheat Varieties against Angoumois Grain Moth, Sitotroga cerealella (Olivier) and Construction of its Life Table
}

\section{Safian Murad $\mathbf{M}^{1 *}$ and Batool $\mathbf{Z}^{2}$}

${ }^{1}$ Department of Plant Protection, the University of Agriculture, Peshawar, Pakistan

${ }^{2}$ Department of Bioinformatics and Biotechnology, Govt. College University, Faisalabad Pakistan

\begin{abstract}
A study was conducted to evaluate the relative biochemical basis of susceptibility of six commercial wheat varieties grown in Khyber Pakhtunkhwa, Pakistan, against angoumois grain moth, Sitotroga cerealella (Olivier) (Lepidoptera: Gelechiidae) and construction of its life table at $28 \pm 1{ }^{\circ} \mathrm{C}, 65 \pm 5 \mathrm{R} . \mathrm{H} . \%$ and L:D $16: 8$ hours under laboratory environment. The results were evaluated on the basis of mean pest $S$. cerealella emergence, percent damage, and percent weight loss, male and female emerged along susceptibility index, 1000 grains weight, hardness and chemical composition of test wheat materials. Life table parameters of $S$. cerealella on highly susceptible and least susceptible wheat varieties were compared. On the basis of susceptibility index, variety Sirin (5.002) was recorded least susceptible and variety Pirsbak-2005 (7.832) recorded as highly susceptible. The chemical composition based on protein and carbohydrate contents $(11.15 \%, 72.54 \%)$ revealed that the variety Sirin was recorded least susceptible, while variety Pirsabak-2005 $(12.68 \%, 75.00 \%)$ was noted as highly susceptible. On the basis of life table, the net reproductive rate (10.9) on variety Pirsabak-2005 was higher than variety Sirin (9.4), and the intrinsic rate of increase was also higher on Pirsabak-2005 (30.7) than Sirin (15.9). With respect to doubling time being index of resistance, this time in Pirsabak-2005 was almost half ( 0.01 days) of the Sirin ( 0.02 days), which means that $S$. cerealella can develop more quickly on Pirsabak-2005 germplasm. In summation, relatively least susceptible wheat variety Sirin can be used to increase the level and diversify the basis of resistance to $S$. cerealella in the resistance breeding programs.
\end{abstract}

Keywords: Wheat germplasm; Sitotroga cerealella; Susceptibility; Resistance; Life table

\section{Introduction}

Wheat (TriticumaestivumL.), is the most widely grown crop in the world. Wheat is the staple food, about $40 \%$ of the world's population. This is the main cereal used around the world for making bread [1-5]. Worldwide wheat production is about $90 \%$ and most this is used for human consumption. Wheat is the largest grain crop and staple food for most of peoples in Pakistan. It occupies a central position in agriculture and economy, and thus confirms the importance of the development of agriculture policy. Wheat is cultivated on several million hectares area of the country to help in the huge income generation of the agriculture community.

It is estimated that $5-10 \%$ of world's wheat production is lost due to insect pests during storage. These losses have been reached up to $50 \%$ in tropical countries, where humidity and temperature run high in summers [6]. In Pakistan, 10-15\% post-harvest losses of wheat occur every year. Live adult and immature insects are present in about $75 \%$ of the samples collected from different regions of Pakistan $[7,8]$. The procurement and storage of wheat is handled by public and private agencies to meet the food needs of the peoples. Most of the wheat is retained by the farmers for their own consumption and for seed purpose for sowing the next year crop. The storage capacity in the public sector is inadequate ( 3.34 million tons). In addition, the high moisture content of grain $(>12 \%)$, high temperature $\left(25-30^{\circ} \mathrm{C}\right)$ and relative humidity $(>60 \%)$ during storage period make the environment favorable to the spread of insect pests.

Only $25 \%$ of the annual production is maintained at the appropriate pest control measure in the government warehouses, while the rest is stored under original storage conditions at farm level or temporary made stock store. Since the majority of stockiest and farmers are illiterate and poor, they cannot afford to buy chemicals to protect their produce, as a result quite a large quantity of their wheat is overwhelmed by stored grain insects. In addition, chemical pesticides used in storage are highly toxic causing many health problems.

In Pakistan, wheat is attacked by a number of insect pest species during storage. Besides many coleopteran beetles, lepidopteron Angoumois grain moth Sitotroga cerealella (Olivier) has become a serious problem for stored wheat, maize, sorghum and rice. The infestation of wheat with $S$. cerealella starts in the field as females lay their eggs singly or in groups on grains [9]. The larvae start feeding inside the grains while still in the milk stage, these spend their entire life inside one grain and infestation is difficult to detect at this stage. The adults leave a conspicuous emergence hole at one end of the kernel, infested grains are characterized by this circular window created by the larvae and grains may be completely destroyed. The adults are active fliers, thus, they are able to infest neighboring granaries, consequently stimulating seed deterioration and further fungal activity leading to a reduction in seed germination.

Life table is a characteristic which describes survival of a certain

*Corresponding author: Safian Murad M, Department of Plant Protection The University of Agriculture, Peshawar, Pakistan, Tel: +92 91 9221144; E-mail: miansb87@gmail.com

Received November 26, 2016; Accepted January 25, 2017; Published January 30, 2017

Citation: Safian Murad M, Batool Z (2017) Relative Biochemical Basis of Susceptibility in Commercial Wheat Varieties against Angoumois Grain Moth Sitotroga cerealella (Olivier) and Construction of its Life Table. J Biom Biostat 8 : 333. doi:10.4172/2155-6180.1000333

Copyright: (c) 2017 Safian Murad M, et al. This is an open-access article distributed under the terms of the Creative Commons Attribution License, which permits unrestricted use, distribution, and reproduction in any medium, provided the original author and source are credited. 
age stages, reproduction and development of insect species. The life table contains the basic information needed to study the increase or decrease rate and the rate of change of population. These describe the possibility of an individual and the number of progeny produced by a female of a given age. In ecological research, life table is the one of the most significant analytical tool, which provides detailed information of population, dynamically generated [10-15]. it also provide a complete description of the mean generation time, survival, mortality, total eggs or young one produced per female at age time, doubling time and net reproductive rate. Since there are problems created with chemical control of $S$. cerealella pest, it is significant to recognize the characteristics linked with susceptibility or resistance of wheat and their influence on pest proliferation.

\section{Materials and Methods}

The present experiments were conducted to investigate the relative susceptibility or resistance of commercial wheat varieties grown in Khyber Pakhtunkhwa against stored grain insect pest $S$. cerealella and construction of its life table at Insect Pest Management Program, Institute of Plant and Environmental Protection, National Agriculture Research Center Islamabad under laboratory condition of $28 \pm 1^{\circ} \mathrm{C}, 65$ \pm 5\% R.H.\% and 16:8 (L: D), during 2012 .

\section{Collection of wheat varieties}

The subsequent six commercial wheat varieties of Khyber Putkhtunkhwa i.e., Attahabib, Khyber 87, Pirsabak 2004, Pirsabak 2005, Pirsabak 2008 and Sirin were obtained from Cereal Crop Research Institute, Pirsabak, District Nowshera, and tested for their susceptibility against $S$. cerealella.

\section{Disinfestation of wheat grains}

Healthy, fully matured and sound grains of wheat were used for conducting of present experiment. The wheat varieties were disinfested before using in the experiment by keeping at $5^{\circ} \mathrm{C}$ in a cold incubator for a period of one week to kill any individual invading grains.

\section{Sitotroga cerealella culture maintenance}

The $S$. cerealella culture was maintained on wheat grains under the same laboratory condition $\left(28 \pm 1^{\circ} \mathrm{C}, 65 \pm 5 \%\right.$ R.H.\% and $16: 8$ $\mathrm{L}: \mathrm{D})$ throughout the experimental duration $[16,17]$. The adults were collected from the rearing chamber in glass jars attached to the chamber and placed in a plate containing starch. On the next day the starch was sieved through 80 mesh sieve. After sieving the starch, the eggs were collected and confined in a Petri dish or vial. Some quantity of these eggs was placed in the glass jars containing wheat for maintaining the culture and the remaining eggs were used in the experiment.

\section{Experimental procedure}

The wheat varieties were weighed to each 50 gram sample through Mettler PE 3600 digital weight meter. There were six treatments; each treatment was replicated ten times in Completely Randomized design [18-20]. A control replicate was allotted to each treatment as well. Initially, grain from each genotype was placed in $10 \times 5 \mathrm{~cm}$ glass jars having muslin cloth at the top tighten with rubber band. One hundred nearly to hatching eggs (red colored) were confined in respective treatments jars i.e., replicate wise and the whole stuff was kept in the laboratory under control humidity and temperature [21-23].

Date of seeding was put on label pasted on each jar. The jars were checked daily for adult's emergence, starting after 20 days of seeding daily. Date of first adult emergence was recorded in order to know the developmental period. On emergence, the number of adults was counted. Developmental period of first generation was calculated by subtracting the initial seeding date from emergence date. The total number of insects in first generation was counted and then dead adults were removed [24,25]. The experiment was continued up to two generations of $S$. cerealella. Second generation adults' emergence was recorded and added to first one. This gave total progeny. At the termination of the experiment, each sample was passed through a 60-mesh sieve for separation of frass and grains. The dust passed was discarded while weight of remaining grains was taken [26,27].

The grains containing adult emerging holes were separated from the sound grain and \% damage was calculated according to following formula.

$$
\% \text { Damage }=\frac{(\text { Wt. of control sample }- \text { Wt. of sound grains in test sample })}{\text { Wt. of control sample }} \times 100
$$

Percent weight loss was also recorded and calculated according to the following formula reported [28].

$\%$ Weight loss $=\frac{[\text { Wt. of control sample }-(\text { wt. of sound grains }+ \text { Wt. of damaged grains }]}{\text { Wt. of control sample }} \times 100$

Susceptibility index of S. cerealella was determined on all the varieties

for the confirmation of highly susceptible and least susceptible [29]. For the susceptibility of wheat varieties developmental period of $S$. cerealella was determined on all the varieties. The susceptibility index was calculated by the following formula Susceptibility index $=\frac{\log _{\mathrm{e}} . \mathrm{F} \times 100}{\mathrm{D}}$.

Where $\mathrm{F}$ : is the total number of adult emerged and $\mathrm{D}$ : is mean developmental period.

\section{Proximate analysis of wheat varieties}

Proximate Analysis comprised a partitioning of compounds in a feed into six categories based on the chemical properties of the compounds [30,31]. The whole analysis was carried out at the Grain Quality Testing Lab at National Agriculture Research Council. Proximate composition of the grains (i.e., determination of moisture, crude protein, crude fat, crude fiber, ash and carbohydrates) was performed in accordance with the standard method of Association of Official Analytical Chemists Washington.

\section{Life table studies}

Life table comprised a most important analytical tool, which provided detailed information of population dynamics to generate simple but more informative statistics. To calculate life table of $S$. cerealella on two wheat varieties i.e., highly susceptible variety and least were selected susceptible out of tested varieties [32]. The highly susceptible wheat variety was Pirsabak 2005, while least susceptible appeared to be Sirin. For the construction of life table 10 pairs of male and females of known age were collected, confined in small vials $(3 \times$ $\left.1^{\prime \prime}\right)$ and covered with lid of 75 mesh size sieve and placed upside down on the dish containing starch of both varieties. After 24 hours the data collection were started and the starch was sieved with 85 mesh size sieve. The eggs were collected daily and the process was continued till the death of all females in the experiments [33].

The collected eggs were kept in other plastic vials on paper strip to check the hatching. Upon hatching the larvae were fed on the above mentioned varieties up to adult's emergence in the next generation. Ten total adults emergence and numbers of female progeny per day per female were calculated. The following parameters were calculated:- 
Citation: Safian Murad M, Batool Z (2017) Relative Biochemical Basis of Susceptibility in Commercial Wheat Varieties against Angoumois Grain Moth Sitotroga cerealella (Olivier) and Construction of its Life Table. J Biom Biostat 8: 333. doi:10.4172/2155-6180.1000333

Page 3 of 7

$\mathrm{T}=$ mean generation time, $\mathrm{DT}=$ doubling time, $\mathrm{Lx}=$ survivorship of female from birth to adult living, $\mathrm{Dx}=$ mortality rate, $\mathrm{Mx}=$ mean fecundity rate, GRR=mean total number of eggs produced by a female over its life time, $\mathrm{Ro}=$ net reproductive rate, $\mathrm{R}_{\mathrm{m}}=$ intrinsic rate of increase. For mean generation time $\mathrm{T}$ the mean data from egg to adult were taken, mean fecundity rate i.e., mean number of eggs laid by female.

Doubling time was calculated by formulas: DT $=\log 2 / \mathrm{r}_{\mathrm{m}}$

Survival rate was calculated by: $\mathrm{Lx}=\frac{\text { Number of eggs survived }}{\text { Total number of eggs }}$

Net reproductive rate was calculated by formulas: $\mathrm{Ro}=\Sigma \mathrm{Lx} . \mathrm{Mx}$

Intrinsic rate of increase was calculated by: $\mathrm{R}_{\mathrm{m}}=\frac{\text { Total numbers of female }}{\text { Total number of replications }}$.

\section{Results}

\section{Relative susceptibility study}

The present research conducted determined the relative susceptibility of different commercial wheat varieties grown in Khyber Pakhtunkhwa against stored grain insect pest $S$, cerealella damage, percent weight loss, number of male and female emerged, susceptibility index, 1000 grain weight, hardness, chemical composition and life table parameters.

Adults emergence, percent damage, percent weight loss and numbers of male and female emerged are presented in Table 1. The highest number of adult emergence (86.4) was in Pirsabak-2005 followed by Khyber-87 (69.4), Pirsabak-2008 (66.4) and Pirsabak-2004 (64.2), while it was lowest in Sirin (28.4) followed by Attahabib (43.1). The statistical analysis showed that the emergence in Pirsabak-2005 was significantly different from Sirin and Attahabib, however, no significantly difference was recorded in Khyber-87, Pisabak-2008 and Pirsabak-2004.

Percent damage was highest in Pirsabak-2005 (59.5\%) followed by Khyber-87 (48.6\%), Pirsabak-2008 (46.6\%) and Pirsabak-2004 (41.8\%), while it was lowest in Sirin (25.1\%) followed by Attahabib(35.2\%). The statistical analysis revealed that all the varieties were significantly different from each other. Percent weight loss by $S$. cerealella was observed higher in Pirsabak-2005 (34.3\%), followed by Pirsabak-2008 (28.6\%), Khyber-87 (27.3\%) and Pirsabak-2004 (24.3\%), while the lowest percent weight loss was observed in Sirin (7.7\%) followed by Attahabib (10.1\%). The statistical analysis showed that all the varieties were significantly different from each other.

Highest number of males of S. cerealella emerged in Pirsabak-2005 (40.6\%), Khyber-87 (30.8\%), Pirsabak-2008 (30.4\%) and Pirsabak-2004 (29.7\%), while the lowest numbersemergence (7.2\%) was inSirin and in Attahabib (19.1\%). The multiple comparisons showed that male emergence in Pirsabak-2005 was significantly different from Sirin and Attahabib, while no significant differences were observed in Pirsabak-2008, Khyber-87 and Pirsabak-2004.

On the other hand, highest female emergence was recorded in Pirsabak-2005 (45.8\%) followed by Khyber-87 (37.6\%), Pisabak-2008 (36.0\%) and Pirsabk-2004 (34.5\%). The lowest female emergence was observed in Sirin (11.0\%) and Attahabib (24.0\%). Statistical analysis revealed that female emergence in Pirsabak-2005 was significantly differentthan Sirin and Attahabib, however, no significant difference was found in Khyber-87, Pirsabak-2004 and Pirsabak- 2008, respectively.

The results for multiple comparison of susceptibility index are presented in Table 2. The susceptibility index was highest (7.832) in Pirsabk-2005 followed by Khyber-87 (7.220), Pirsabk-2008 (6.980) and Pirsabak-2004 (6.890), while the lowest susceptibility index was found in Sirin(5.002) and Attahabib 5.875). The statistical analysis for susceptibility index showed that Pirsabak-2005 was significantly different from Sirin. Sirin and Attahabib are significantly different from the other varieties such as Khyber-87, Pirsabak-2004 and Pirsabak-2008. But Khyber-87, Pirsabk-2004 and Pirsabak-2008 are not significantly different from one another.

The results for 1000 grains weight and hardness are presented in Table 2. The highest grains weight (43.7 gm) was recorded in Pirsabak-2005 followed by Khyber-87 (40.2 gm), Attahabib (39.1 gm), Pirsabak-2004 (38.2 gm), while lowest (35.1 gm) was noted in Sirin and Pirsabak-2008 (37.3 gm). Statistical analysis for 1000 gains weight showed that all the varieties were significantly different from each other.

It is revealed from the results that highest hardness was (31.5\%) in Sirin, Attahabib (30.3\%), Pirsabak-2004 (30.1\%), while lowest was (24.3\%) in Pirsabak-2005 (24.3\%), Khyber-87 (27.4\%) and Pirsabak-2008 (29.4\%). The statistical analysis for hardness showed that the Sirin was significantly different from all of the other varieties $[34,35]$. The varities Attahabib and Pirsabak-2004 are non-significant. Pirsabak-2008 was significantly different from Attahabib, Khyber-87 and Pirsabak-2004. Khyber-87 was significantly different from Attahabib, Pirsabak-2008 and Pirsabak-2005. Pirsabak-2005 was significant different from rest of the varieties.

\section{Proximate analysis of wheat varieties}

The results for chemical composition are presented in Table 3 . Higher moisture content was recorded in Pirsabak-2005 (9.18\%) followed by Pirsabak-2004 (9.16\%) and Khyber-87 (9.06\%), while it was lower in Sirin (8.93\%), Attahabib (8.93\%) and Pirsabak-2008 (8.97\%). The statistical analysis revealed that the varieties Pirsabk-2004, Pirsabak-2005 and Khyber-87 did not differ in moisture content. Khyber-87, Pirsabak-2004 and Pirsabak-2005 are significantly different from rest of the varieties.

\begin{tabular}{|c|c|c|c|c|c|}
\hline Variety & Number of male emerged \pm S.E & $\%$ Weight loss \pm S.E & $\%$ Damage \pm S.E & $\%$ Male emergence \pm S.E & \%Female emergence \pm S.E \\
\hline Attahabib & $43.1 \pm 0.99 c$ & $10.1 \pm 0.01 \mathrm{e}$ & $35.2 \pm 0.08 \mathrm{e}$ & $19.1 \pm 0.67 c$ & $24.0 \pm 0.55 c$ \\
\hline Khyber-87 & $69.4 \pm 3.57 b$ & $27.3 \pm 0.09 c$ & $48.6 \pm 0.09 b$ & $30.8 \pm 2.17 b$ & $37.6 \pm 1.88 b$ \\
\hline Pirsabak-2004 & $64.2 \pm 3.85 b$ & $24.3 \pm 1.10 \mathrm{~d}$ & $41.8 \pm 0.08 d$ & $29.7 \pm 2.16 b$ & $34.5 \pm 1.71 b$ \\
\hline Pirsabak-2005 & $86.4 \pm 1.29 a$ & $34.3 \pm 0.10 a$ & $59.5 \pm 0.13 a$ & $40.6 \pm 0.71 \mathrm{a}$ & $45.8 \pm 1.08 \mathrm{a}$ \\
\hline Pirsabak-2008 & $66.4 \pm 2.31 b$ & $28.6 \pm 0.11 b$ & $46.6 \pm 0.12 \mathrm{c}$ & $30.4 \pm 1.33 b$ & $36.0 \pm 1.21 \mathrm{~b}$ \\
\hline Sirin & $28.4 \pm 1.85 \mathrm{~d}$ & $7.7 \pm 0.06 f$ & $25.1 \pm 0.01 \mathrm{f}$ & $7.2 \pm 0.44 d$ & $11.0 \pm 0.53 d$ \\
\hline $\operatorname{LSD}(\alpha=0.05)$ & 7.2 & 0.2 & 0.2 & 4.0 & 3.6 \\
\hline
\end{tabular}

Note: Mean values in the same column followed by similar letters are not significantly different at $P \leq 0.05$, ANOVA followed by LSD test.

Table 1: Mean emergence, weight loss, damage and males and females emergence $\%$ of $S$. cerealella on wheat varieties. 
Citation: Safian Murad M, Batool Z (2017) Relative Biochemical Basis of Susceptibility in Commercial Wheat Varieties against Angoumois Grain Moth, Sitotroga cerealella (Olivier) and Construction of its Life Table. J Biom Biostat 8: 333. doi:10.4172/2155-6180.1000333

Page 4 of 7

\begin{tabular}{|l|c|c|c|}
\hline \multicolumn{1}{|c|}{ Varieties } & Susceptibility index & $\mathbf{1 0 0 0}$ Grain weight \\
\hline Attahabib & $5.875 \mathrm{~d}$ & $39.1 \mathrm{c}$ \\
\hline Khyber-87 & $7.220 \mathrm{~b}$ & $40.2 \mathrm{~b}$ \\
\hline Pirsabak-2004 & $6.890 \mathrm{c}$ & $38.2 \mathrm{~d}$ \\
\hline Pirsabak-2005 & $7.832 \mathrm{a}$ & $43.7 \mathrm{a}$ \\
\hline Pirsabak-2008 & $6.980 \mathrm{bc}$ & $37.3 \mathrm{e}$ \\
\hline Sirin & $5.002 \mathrm{e}$ & $30.1 \mathrm{~b}$ \\
\hline LSD $(0.05)$ & 0.24 & $24.3 \mathrm{e}$ \\
\hline
\end{tabular}

Note: Mean values in the same column followed by similar letters are not significantly different at 0.05 level of significance, ANOVA followed by LSD test. Table 2: Mean susceptibility index, thousand grain weight and hardness for wheat varieties.

\begin{tabular}{|c|c|c|c|c|c|c|}
\hline Varieties & Moisture (\%) & Protein (\%) & Ash (\%) & Fat (\%) & Fiber (\%) & Carbohydrate (\%) \\
\hline Attahabib & $8.93 \mathrm{~b}$ & $11.51 \mathrm{c}$ & $1.86 \mathrm{~b}$ & $1.56 \mathrm{ab}$ & $2.06 \mathrm{c}$ & $73.16 \mathrm{~d}$ \\
\hline Khyber-87 & $9.06 a b$ & $12.29 b$ & $1.44 \mathrm{f}$ & $1.65 \mathrm{a}$ & $2.27 \mathrm{a}$ & $73.38 \mathrm{c}$ \\
\hline Pirsabak-2004 & $9.16 \mathrm{a}$ & $11.45 \mathrm{c}$ & $1.70 \mathrm{e}$ & $1.62 \mathrm{a}$ & $2.01 \mathrm{~d}$ & $74.41 \mathrm{~b}$ \\
\hline Pirsabak-2005 & $9.18 \mathrm{a}$ & $12.68 \mathrm{a}$ & $1.75 \mathrm{c}$ & $1.56 \mathrm{ab}$ & $1.68 \mathrm{e}$ & $75.00 \mathrm{a}$ \\
\hline Pirsabak-2008 & $8.97 \mathrm{~b}$ & $12.28 \mathrm{~b}$ & $1.72 \mathrm{~d}$ & $1.50 \mathrm{~b}$ & $2.26 \mathrm{a}$ & $73.01 \mathrm{e}$ \\
\hline Sirin & $8.93 \mathrm{~b}$ & $11.15 \mathrm{~d}$ & $1.96 \mathrm{a}$ & $1.60 \mathrm{~b}$ & $2.14 \mathrm{~b}$ & $72.54 \mathrm{f}$ \\
\hline LSD (0.05) & 0.14 & 0.10 & 0.10 & 0.01 & 0.01 & 0.01 \\
\hline
\end{tabular}

Note: Mean values in the same column followed by similar letters are not significantly different at 0.05 level of significance, ANOVA followed by LSD test. Table 3: Mean chemical composition of wheat varieties.

\begin{tabular}{|c|c|c|}
\hline \multirow[t]{2}{*}{ Life Table Parameters } & \multicolumn{2}{|c|}{ Wheat Varieties } \\
\hline & Pirsabak-2005 & Sirin \\
\hline Adult survival rate $(L x) \%$ & 50 & 50 \\
\hline Gross Reproduction rate (GRR) Female/female/day & 21.9 & 18.9 \\
\hline Net Reproductive rate $\left(r_{m}\right)$ Female/female/day & 10.9 & 9.4 \\
\hline Intrinsic rate of increase $\left(R_{o}\right)$ days & 30.7 & 15.9 \\
\hline Generation Time $(\mathrm{T})$ days & 33.9 & 41.7 \\
\hline Death Rate (Dx)\% & 50 & 50 \\
\hline
\end{tabular}

Table 4: Life table parameters of S. cerealella on highly susceptible (Pirsabak-2005) and least susceptible variety (Sirin).

Highest crude protein was examined (12.68\%) in Pirsabak-2005, Khyber-87 (12.29\%) and Pirsabak-2008 (12.28\%), while lowest in Sirin (11.15\%), Attahabib (11.51\%) and Pirsabak-2004 (11.45\%). Statistical analysis showed that Pirsabak-2005 was significantly different from Sirin, and Attahabib and Pirsabak-2004 are not significantly different from one another. Similarly, Khyber-87 and Pirsabak-2008 are also not significantly different from each other. However, these two groups are significantly different from each other [36,37].

Ash contents in all six varieties of the tested wheat are significantly different from one another. Highest content was recorded in wheat variety Sirin, while the lowest in Khyber- 87 . These genotypes are graded as $1.44<1.70<1.72<1.75<1.86<1.96$ in Khyber-87, Pirsabak-2004, Pirsabak-2008, Pirsabak-2005, Attahabib and Sirin, respectively.

For crude fat no statistical difference was noted among Attahabib, Khyber-87, Pirsabak-2004 and Pirsabak-2005. Similarly, no statistical difference was observed in Attahabib, Pirsabak-2005, Pirsabak-2008 and Sirin. However, Khyber-87 and Pirsabak-2004 were statistical different from Pirsabak-2008 and Sirin wheat varieties.

The results for crude fiber were higher $(2.27 \%)$ in Khyber-87, Pirsabak-2008 (2.26\%), Sirin (2.14\%), while it was found lower in Pirsabak-2005 (1.68\%), Pirsabak-2004 (2.01\%) and Attahabib (2.06\%). The statistical analysis showed that the varieties Khyber-87 and Pirsabak-2008 are non-significantly different from one another. Khyber-87 and Pirsabak-2008 are significantly different from rest of the varieties.

The total carbohydrate contents were found higher (75.00\%) in Pirsabak-2005 followed by Pirsabak-2004 (74.41\%), Khyber-87 (73.38\%) and Attahabib (73.16\%), while it was found lower in Sirin (72.54\%) followed by Pirsabak-2008 (73.01\%). The statistical analysis revealed that all the varieties are significantly different from each other.

\section{Life table study}

Results for life table parameters of $S$. cerealella are presented in Table 4. It is revealed from the results that adult survival rate $(\mathrm{Lx})$ and death rate $(\mathrm{Dx})$ of $S$. cerealella was similar at both highly susceptible and least susceptible varieties i.e., Pirsabak-2005 and Sirin, respectively. However, Gross Reproductive Rate (GRR), Net Reproductive rate $(\mathrm{rm})$, Intrinsic rate of increase (Ro) were higher in high susceptible variety Pirsabak-2005 than least susceptible varietsy Sirin. On the other hand, mean generation time $(\mathrm{T})$, was lower in high susceptible variety (Pirsabak-2005) than least susceptible variety Sirin i.e., 33.9 and 41.7 days, respectively.

Similarly, longevity/survival and fecundity of $S$. cerealella were higher on high susceptiblevariety Pirsabak-2005 (Figures 1 and 2) than least susceptible variety Sirin (Figures 3 and 4).

\section{Discussion}

The present studies were conducted to study the resistance behavior of six commercial wheat varieties grown in Khyber Pakhtunkhwa against $S$. cerealella. The life table of $S$. cerealella on most susceptible and least susceptible varieties was constructed for comparison. Resistance of grains to stored grain insect pests depends upon multiple factors. Some of the important factors are variety, insect species, grain weight 


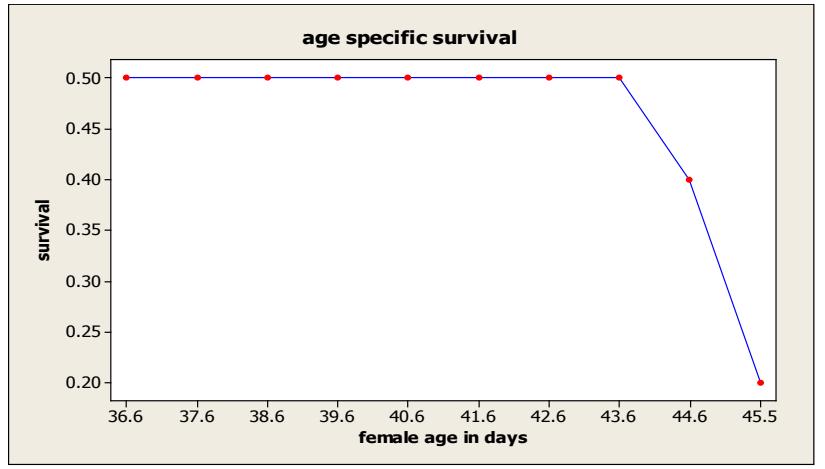

Figure 1: Age specific survival of S. cerealella on variety Pirsabak-2005.

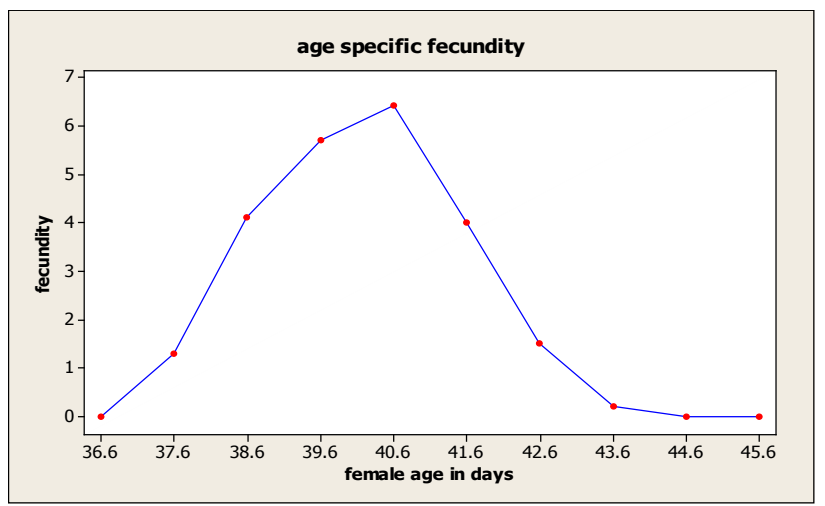

Figure 2: Age specific fecundity of S. cerealella on variety Pirsabak-2005.

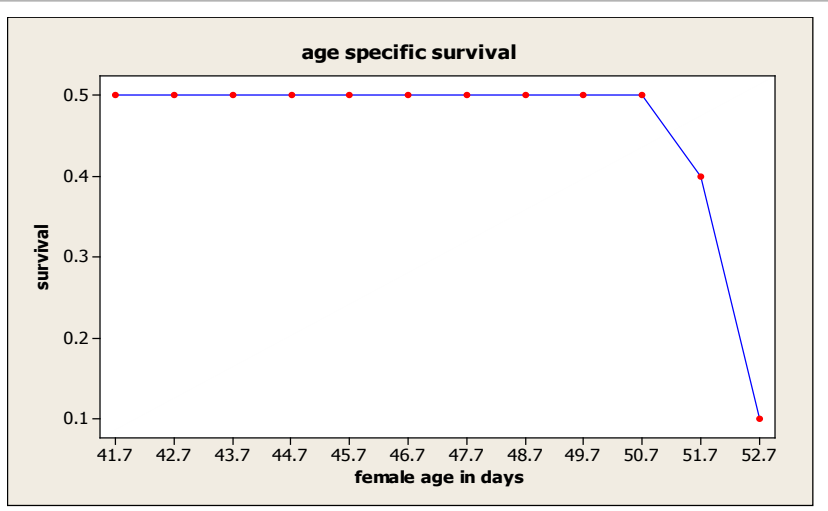

Figure 3: Age specific survival of S. cerealella on variety Sirin.

and chemical composition. Within variety there could be variations like texture, smooth or rough surface and chemical constituents of the grains.

All the varieties differed in grain weight and chemical composition, hence their response varied significantly to the attack of this insect. The results indicated that lowest emergence of $S$. cerealella was recorded in Sirin and highest observed in Pirsabak-2005. Therefore, our current results are in close conformity, who reported that the number of emerged stored insects is a better indicator of seed resistance than the number of eggs present on the seed.

All the varieties have different index of susceptibility. The highest index of susceptibility index was found in Pirsabak-2005, while lowest

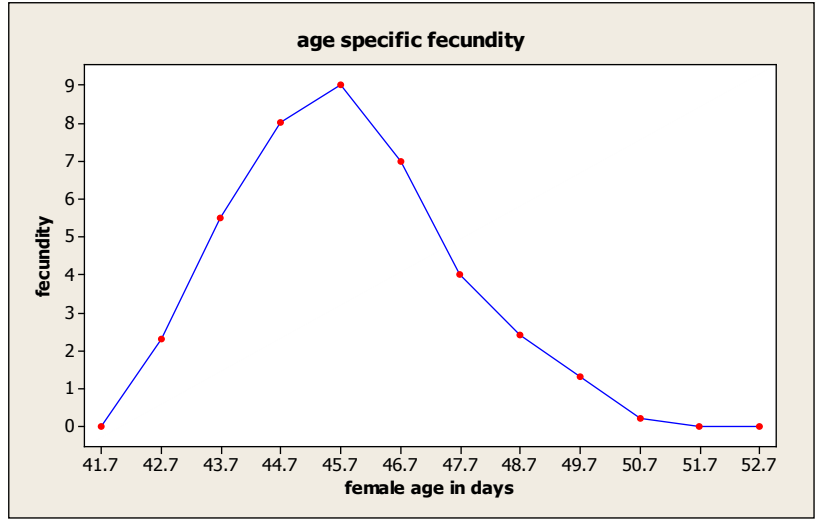

Figure 4: Age Specific Fecundity of S. cerealella on variety Sirin.

in Sirin. As the adult emergence increased, the index of susceptibility also increased. Our results are similar, who reported that the increase in adult emergence also increased the susceptibility index.

All the varieties were different in percent damage and percent weight loss. The highest percent damage was recorded in Pirsabak-2005, while the lowest percent damage noted in Sirin. Similarly, the highest percent weight loss was recorded in Pirsabak-2005, while the lowest found in Sirin. The protein is also an important factor in determining the susceptibility level. The highest protein content was recorded in Pirsabak-2005, while the lower recorded in Sirin. The carbohydrate content could also be a positive factor in increasing the percent damage and percent weight loss. Therefore, our results are in close conformity with the work, who found that the variety with more protein was more susceptible, while that variety which has low protein was least susceptible. Similarly, every increase of one percent in carbohydrates contents, the percent damage and percent weight loss increased by 7.12 and 0.34 , respectively.

The grain weight of Pirsabak-2005 was higher than Sirin. The possible reason for susceptibility in that might of larger grain weight of the former varieties as compared to later. This could also be owing to lowest hardness that was recorded in Pirsabak-2005, while highest found in Sirin. Our results are in close conformity, who found that weight of large grains of maize and wheat was reduced more by the attack of $S$. cerealella than that of small grains, and more eggs were laid by female developed from larvae that developed in large grain than by those from larvae in small grains. A relative hard variety undoubtedly reduces the successful entry of newly hatched $S$. cerealella larvae into kernels. The same was observed in our study that the hardness of variety Sirin was more than Pirsabak-2005. Similarly, our results are also in conformity with the results, who reported that bean beetle infestation decreases with kernel hardness.

No oviposition was observed within 24 hours after female emergence during a preliminary study. So, the females used for the life study were up to 24 hours old. In this study the life table parameters including gross reproductive rate (GRR), net reproductive rate (Ro), intrinsic rate of increase $(\mathrm{Rm})$, and mean generation time $(\mathrm{T})$ showed that all the parameters observed was higher in variety Pirsabak-2005, except the adult survival rate $(\mathrm{Lx})$ and death rate $(\mathrm{Dx})$ which was similar in both the varieties.

The highest net reproductive rate observed in variety Pirsabak-2005 at $28^{\circ} \mathrm{C}$ and $65 \pm 5 \%$ R.H., while the lowest recorded on Sirin. The gross reproductive rate was higher on variety Pirsabak-2005, as compared to 
Citation: Safian Murad M, Batool Z (2017) Relative Biochemical Basis of Susceptibility in Commercial Wheat Varieties against Angoumois Grain Moth Sitotroga cerealella (Olivier) and Construction of its Life Table. J Biom Biostat 8: 333. doi:10.4172/2155-6180.1000333

Page 6 of 7

Sirin. The results are in close conformity to the results, who studied the biology of $S$. cerealella on a commercial maize variety and four mutant varieties at $30^{\circ} \mathrm{C}$ and $65 \%$ R.H., and they found significant differences between the performances of the test insect on some of the different maize genotypes. Thus, our present results are similar to their previous results.

The intrinsic rate of natural increase $\left(r_{m}\right)$ is probably the best parameter to compare pest species and varieties. The highest intrinsic rate of increase was observed on Pirsabak-2005, while lowest on Sirin. Our results are in conformity, who found two important parameters in calculation of intrinsic rate of natural increase i.e., longevity and fecundity of $S$. cerealella were higher on one variety than others. Accordingly, the life table parameters confirm that the variety Sirin is least susceptible to $S$. cerealella as compared to Pirsabak-2005.

\section{Conclusions}

The comparative susceptibility of various wheat varieties to $S$. cerealella in the present studies has great future prospects of safe storage. This information of course, to all concerned agencies is a valuable contribution towards stored grain research and wheat food self-sufficiency programs in Pakistan, which will further strengthen our economy by reducing insect losses through evolving insect resistance varieties.

It is concluded from the above discussion that considering emergence, percent damage and percent weight loss as parameter factors of susceptibility response in the six varieties, and life table parameters of $S$. cerealella on most susceptible and least susceptible germplasm. Variety Sirin emerged as a significantly least susceptible variety, while Pirsabak-2005 found the most susceptible one. Also the variety Khyber- 87 showed less susceptibility to the pest and has bright future prospects in breeding program.

Now a day's Trichogramma spp, (egg parasite) are encouraged as biocontrol agent for controlling of many serious Lepidopterous pests i.e., Helicoverpa spp., and borers etc. These parasites are reared in laboratories on $S$. cerealella eggs. Therefore, it is suggested that Pirsabak-2005 the most susceptible variety and best for mass production of $S$. cerealella can be recommended for Trichogramma rearing, further research needs to be done to screen and evaluate more varieties against $S$. cerealella and also find the genes of resistance in wheat against $S$. cerealella. It is also suggested that breeders should concentrate efforts on evolving varieties that have potential yield and more insect resistance level.

\section{References}

1. Sarwar M, Sattar M (2007) Varietals assessment of different wheat varieties for their resistance response to khapra beetle Trogodermagranarium. Pakistan Journal of Seed Technology 1: 1-7.

2. Ahmad H (1983) Losses incurred in stored grains by insect pests - A review. Pakistan J Agric Res 4: 198-207.

3. Ahmad M, Irshad M, Shahid M (1998) Loss assessment in stored wheat in three villages of Gilgit. Pak J Zool 30: 41-46.

4. Ahmad S, Mansoor H, Saleeem H (2002) Studies on the relative susceptibility of wheat varieties to Sitotroga cerealella (Oliv.) Pak J Agri Sci 39: 47-49.

5. Ali A, Sarwar M, Khanzada S, Abro GH (2011) Evaluating Resistance of Wheat Germplasms to Attack by Red Flour Beetle Tribolium castaneum (Herbst) (Coleoptera). Pak J Zool 43: 793-797.

6. Ali A, Sarwa M, Khanzada S, Abro GH ( 2009) Reaction of Certain Whea Varieties to the Action of Red Flour Beetle, Triboliumcastaneum (Herbst) (Coleoptera) Under Insectary Conditions. Pak J Zool 41: 51-56.
7. AOAC (1990) Official Method of Analyst. Association of Official Analytical Chemist Washington, DC, USA, p: 632.

8. Dobie P, Kilminster AM (1977) The susceptibility of triticale to post-harvest infestation by Sitophilus zeamaisMotsch, S. oryzae (L.) and S. granarius (L.). Trop Stored Prod Res 14: 87-93.

9. Hensen LS, Skovgard H, Hell K (2004) Life table study of Sitotroga cerealella (Lepidoptera: Gelechiidae), a strain from West Africa. J Econ Entomol 97: 1484-1490.

10. Hina HK, Sarwar M, Lohar MK (2015) Repellence Activity of Plant Oils against Red Flour Beetle Triboliumcastaneum (Herbst) (Coleoptera: Tenebrionidae) in Wheat. International Journal of Animal Biology 1: 86-92.

11. Hudson TH, William IF, Anton MK (1981) Plant Science Growth, Development and utilization of cultivated plants. Pretice-Hall Inc Englewood cliffs, New Jersey 07632, p: 676.

12. Imura O, Sinha R (1989) Principal component analyses of bagged wheat infested with Sitotroga cerealella (Lepidoptera: Gelechiidae) and Sitophilus oryzae (Coleoptera: Curculionidae). Ecological Research 4: 199-208.

13. Iqbal M, Khattak SUK, Hussain N, Hameed M (1988) Combined infestation and losses caused by three storage insects in Pak-81 wheat variety. Nucleus Karachi 25: 23-26.

14. Irshad M (1997) Intrinsic rate of growth of various stored grain pests in different ecologies. Pak J Zool 29: 91-92.

15. Irshad M, Gillani WA (1988) Resistance in some wheat varieties to the attack of Sitophilus oryzae (L.) and Sitotroga cerealella (Oliv.) during storage. Pak Ento Kar 8: 85-94.

16. Irshad M, Gillani WA, Khan A (1988) Maize grain resistance to Sitotroga cerealella and Sitophilus oryzae. Pak J Agric Res 9: 539-542.

17. Khan I, Afsheen S, Nafees UD, Khattak SUK, Khalil SK, et al. (2010) Appraisa of different wheat genotypes against Angoumois grain moth, Sitotroga cerealella (Oliv.). Pak J Zool 42: 161-168.

18. Khattak SUK, Shafique M (1981) Susceptibility of some wheat varieties to Angoumois grain moth, Sitotroga cerealellaOliv. (Lepidoptera: Gelechiidae) Pak J Zool 13: 99-103.

19. Khattak SUK, Hameed M, Khatoon R, Mohammad T (1991) Post-harvest damage and losses caused by S. cerealella in different wheat cultivars. Bang J Zool 19: 29-33.

20. Khattak SUK, Munaf A, Khalil SK, Alamzeb, Hussain N (1996) Relative susceptibility of wheat cultivars to Sitotroga cerealella (Olivier). Pak J Zool 28 $115-118$

21. Koleva LA, Acad G (2009) A Study on the Life Cycle of Angoumois Grain Moth Sitotroga cerealellaOliv. (Lepidoptera: Gelechiidae) during Feeding on Different Wheat Genotypes (TriticumaestivumL.). J of Plant Sci 46: 130-134.

22. Manojlovic $B$ (1987) The influence of wheat and maize grain weight and number of larvae on the harmfulness, survival and fertility of angoumois grain moth $\mathrm{S}$. cerealella (Olivier). ZastitaBijla 38: 207-224.

23. Mansha M (1985) Physical and biochemical factors affecting the relative susceptibility of different gram varities to C. maculates. M.Sc Thesis, Uni of Agri Faisalabad.

24. Mehdi MT, El-Najjar SJT (1988) The effect of certain varieties of wheat and barley on the biology of the laboratory reared first generation of Angoumois grain moth, Sitotroga cerealella Olivier (Lepidoptera: Gelechiidae). Arab J Plant Prot 6: 64-70.

25. Mercedes M, Jerson M, Fonaiap (1985) Biology of Sitotroga cerealella (Lepidoptera: Gelechidae) stored grain moth in Venezuela. Tropical Agronomy 35: $117-12$

26. Mohapatra H, Khare BP (1989) Effect of some wheat cultivars on the growth and development of angoumois grain moth S. cerealella. Indian J Plant Prot 14: 259-262.

27. Omer EE, Kamel AH (1980) Assessment of damage in some stored cerea grains due to insect attack. Bull. De. La Soci Entomo Egypte 1981: 119-127.

28. Saadia R, Hameed M, Naheed A, Afghan A (2011) Resistance in Stored Rice Varieties against Angoumois Grain Moth, Sitotroga cerealella (Olivier) (Lepidoptera: Gelechiidae). Pak J Zool 43: 343-348. 
Citation: Safian Murad M, Batool Z (2017) Relative Biochemical Basis of Susceptibility in Commercial Wheat Varieties against Angoumois Grain Moth, Sitotroga cerealella (Olivier) and Construction of its Life Table. J Biom Biostat 8: 333. doi:10.4172/2155-6180.1000333

29. Sarwar M (2008) Laboratory studies on different wheat genotypes for their resistance against Khapra Beetle TrogodermagranariumEverts (Coleoptera: Dermestidae). Pakistan Journal of Seed Technology 2: 46-53.

30. Sarwar M (2009) Evaluating wheat varieties and genotypes for tolerance to feeding damage caused by Triboliumcastaneum (Herbst) (Coleoptera: Tenebrionidae). Pakistan Journal of Seed Technology 2: 94-100.

31. Sarwar M (2012) Assessment of resistance to the attack of bean beetle Callosobruchus maculatus (Fabricius) in chickpea genotypes on the basis of various parameters during storage. Songklanakarin Journal of Science and Technology 34: 287-291.

32. Sarwar M (2015) Categorization of Some Advanced Local Wheat Lines against Triboliumcastaneum (Herbst) (Coleoptera: Tenebrionidae). International Journal of Life Science and Engineering 1: 108-113.

33. Sarwar M, Sattar M (2012) Appraisal of Different Plant Products against
TrogodermagranariumEverts to Protect Stored Wheat - A Laboratory Comparison. The Nucleus 49: 65-69.

34. Sarwar M, Ashfaq M, Ahmad N, Randhawa MAM (2013) Assessing the Potential of Assorted Plant Powders on Survival of Caloglyphus Grain Mite (Acari: Acaridae) in Wheat Grain. International Journal of Agricultural Science and Bioresource Engineering Research 2: 1-6.

35. Shafique M, Chaudary MA (2007) Susceptibility of maize grains to storage insects. Pak J Zool 39: 77-81.

36. Shafique M, Ahmad M, Chaudary MA (2006) Evaluation of wheat varieties for resistance to Angoumois grain moth, Sitotroga cerealella (Olivier) (Lepidoptera: Gelechiidae). Pak J Zool 38: 7-10.

37. Tirmzy SH, Munshi GH, Abro GH (1989) Relative susceptibility of different commercial wheat varieties to Sitotroga cerealella (Olivier) during storage. Proc Pak Congr Zool 9: 255-258. 